\title{
The Status of Foreign Labor Migration of Bardiya District in Nepal
}

Bed Prasad Neupane*

\begin{abstract}
This research paper attempts to describe the overseas migration of Bardiya District in Nepal. The main objective of this study is to examine the foreign labor migration from Nepal to Gulf countries including Malaysia. Among many other castes/ethnicities in Nepal, Tharu caste occupies the high percentage. The population of Tharu caste is 56,062 in the study area. Majority of the Tharu people are involved in agriculture sector as it is the traditional occupation. Moreover, this community holds less percentage of agriculture land in the study area. They are still farming the land with conservative and traditional methods and they are far from the modern technology of agriculture. Due to unemployment and insufficient agricultural land, most of the Tharu people migrate to Gulf countries. Selection for Gulf countries as destination by Tharu people in the study area is due to the low privilege households and lack of skill in this manpower. The Government of Nepal should guarantee/manage safer and better foreign labor migration especially in such type of caste/ethnicity.
\end{abstract}

Key words: Migration, emigration, marital status, surplus \& inflow of remittance.

\section{Introduction}

Migration is the third component of population change. Historically, it has dominant role in determining the population size, growth and distribution. Migration can have a direct effect on poor people's livelihoods that migrants send money to their families to sustain livelihoods and social relations. Migration can also act as a social security mechanism for poor households. For many poor households and individuals across the world, remittances constitute a major source of income, insurance and capital accumulation. The outcomes can flow direct into the pockets of the poor-but they can also be indirect. The livelihood outcome depends on a number of issues of migration (Nyberg, 2002).

*Mr. Neupane is a Teaching Assistant at the Department of Population Studies, Patan Multiple Campus, TU, Lalitpur, Nepal. E-mail: nbedprasad@gmail.com 
United Nation's Multilingual Demographic Dictionary defines migration as "A form of geographical mobility or special mobility between one geographical unit and another generally involving change in residence from the place of origin to the place of destination" (UN, 1973). Migration has been classified into internal and international. The movement of people within the country is known as internal migration and the migration from one country to other countries is known as international migration. All migration is not only the result of poor economic condition but also caused by complex mechanism of social, psychological, political and individual determinants. The economy is linked with people's livelihood. Modern migration system that evolved as a response to the concentration of development activities in the urban center, is mainly guided by better social status and high standard of living. As the majority of the people is poor, migration is mainly for food and better agricultural land in Nepal.

This article concentrates on 'livelihood studies' that may explicitly specify a sustainable and livelihoods approach, a broader livelihoods approach to labor migration, or may simply be a consideration of household well-being that extends beyond income. The poorer families are more likely to migrate for sending remittances to support the families. In some cases, the household that stays put, and that does not have enough activities for a sufficient or sustainable livelihood is dependent on remittances, other resources such as livestock, and social relations and kinship networks; and the literature documents the increased vulnerability resulting from out-migration.

Whilst remittances may be a crucial form of insurance for households engaged in migration, family members that stay put may be very dependent on their male relatives for protection and for loans. The absent population of Nepal has been played a major role in demograpahic, social and ceonomic aspests of the country. The emigration rate of Nepal has found 10.77 per thousend population (CBS,2014).

\section{Objectives}

The main objective of this study is to examine the foreign labor migration from Nepal to Gulf countries including Malaysia. The specific objectives of this study are to identify the causes and consequences of foreign labor migration in the study area.

\section{Statement of the Problem}

Bardiya District is less developed where most of people depend on agriculture. There are not additional job opportunities in factories, industries and offices. Consequently, the people migrate from this place to abroad seeking employment. This situation illustrates the fluctuation 
of labor force migration in Geruwa Gaupalika of Bardiya district. The socio-economic status of the people in this area is poor because of unemployment, lack of agricultural land, unskilled labor and illiteracy. Hence, the challenge is how to manage migration in such way that the positive effects are maximized by making of a win-win situation in socio-economic status of this district. The foreign labor migrants of Nepal have great opportunities in abroad equally there are so many problems such as language, religion, culture, weather and environment. However, labor migrants are obliged to work for sending remittance in Nepal.

\section{Methodology}

The selected study area is Geruwa Gaupalika from Bardiya District in Nepal. There are different castes/ethnicities and religious groups having different socio-economic and demographic characteristics. This study investigates and explores the hidden facts of foreign labor migration in the study area. This study is analyzed in a descriptive technique where most of the primary data are used and it is supported by the secondary data too. To collect the primary data, the lists of total household of foreign labor migrants were listed. The required number of sample size in every segment has been calculated using the proportional allocation method. The universe is 574 household of the 1-6 ward of Geruwa Gaupalika and the sampling number 308 households of foreign labor migrant in the wards have been selected using systematic random sampling method.

In this study various types of data collection tools have been applied to collet primary information which is interview, schedule, observation etc.

\section{- Primary Data Collection}

The data has been collected through survey of the migrants' households. Information about socio-economic and demographic characteristics of migrants (age, sex, caste, marital status, education attainment and household assets) are also collected. In this study, the foreign labor migration is defined the emigration at least one year complete as labor migration in the abroad.

\section{- Secondary Data Collection}

The required secondary data are also collected and processed from the office of Geruwa Rural Municipality and population monograph of Nepal. The required number of households and total sample population are also collected from the office of Geruwa Rural Municipality of the Bardiya district. 


\section{Interpretation of the Data and Results}

A household is defined as a person or group of persons who live and eat together. The study attempts to define the socio-economic and demographic characteristics of respondents and households' population. Demographic and socio-economic characteristics play significant role in the development of the society. It provides valuable input in social and economic development in the study area. It is also useful for understanding and identifying the major factors which influences the basic demographic indicators of the population.

Table-1: Distribution of population of Geruwa Rural Municipality, 2015

\begin{tabular}{|c|c|c|c|c|}
\hline $\begin{array}{c}\text { Ward } \\
\text { Numbers }\end{array}$ & $\begin{array}{c}\text { Total } \\
\text { Households }\end{array}$ & Total Population & $\begin{array}{c}\text { Foreign Labor Migrated } \\
\text { Household }\end{array}$ & $\begin{array}{c}\text { Total Sample } \\
\text { Population }\end{array}$ \\
\hline 1 & 938 & 8203 & 110 & 1316 \\
\hline 2 & 1255 & 9889 & 121 & 1395 \\
\hline 3 & 1114 & 8517 & 95 & 1253 \\
\hline 4 & 1365 & 10655 & 118 & 1360 \\
\hline 5 & 1018 & 9375 & 76 & 1172 \\
\hline 6 & 919 & 9423 & 54 & 1053 \\
\hline Total & 6609 & 56062 & 574 & 7549 \\
\hline
\end{tabular}

Source: Field Survey, 2015

Table 1 shows that there are 6609 households in six wards where the total population is 56062 in size. But the households of foreign labor migrants are only 574 where total population is 7549 in size. The highest figure of foreign labor migrants household is 118 in ward no 4 of this Rural Municipality.

\section{Marital Status of Population}

Marital status is an important element of fertility behavior particularly in a noncontraception society and where most of the births take place within marital union as in Nepal (CBS, 2001). The information on marital status of population was obtained from the place of current residence among those aged 15 years and above at the time of survey. The marital status of population of this study is presented in the following table. 
Table-2: Distribution of population by marital status, 2015

\begin{tabular}{|l|c|c|c|c|c|c|}
\hline \multirow{2}{*}{ Marital Status } & \multicolumn{4}{|c|}{ Migrants } & \multicolumn{2}{c|}{ Total } \\
\cline { 2 - 7 } & \multicolumn{2}{|c|}{ Male } & \multicolumn{2}{c|}{ Female } & \multicolumn{2}{c|}{ Percent } \\
\cline { 2 - 7 } & Number & Percent & Number & Percent & Number & 32.6 \\
\hline Unmarried & 130 & 15.9 & 132 & 16.1 & 262 & 60.1 \\
\hline Married & 241 & 29.5 & 251 & 30.7 & 492 & 19 \\
\hline Separated & 8 & 0.9 & 11 & 1.4 & 15 & 1.8 \\
\hline Divorced & 9 & 1.1 & 6 & 0.8 & 30 & 3.7 \\
\hline Widowed & 17 & 2.0 & 13 & 1.6 & 818 & 100 \\
\hline Total & 405 & 49.4 & 413 & 50.6 & & \\
\hline
\end{tabular}

Source: Field Survey, 2015

Table 2 exhibits that the marital status of study population. It shows that 60.1 percent of population is married followed by unmarried with 32.6 percent, widow with 3.7 percent, separated with 2.3 percent and divorce with 1.8 percent respectively.

\section{Caste/Ethnicity and Religion Group of the Population}

Nepal is a one of the multi diversity country in caste and language composition. In Nepal, though there are 125 caste and ethnic groups with distinct language and culture, these diverse caste and ethnic groups (CBS, 2014). Study of caste and ethnic is an important factor in population studies. It demonstrations the socio- economic structure of population composition. The caste of the respondents of this study are categorized into broad four groups: Tharu, Brahmin/Chhetri, Janajati and Dalit.

Table-3: Distribution of the population by caste/ethnicity group, 2015

\begin{tabular}{|l|c|c|c|c|c|c|}
\hline \multirow{2}{*}{$\begin{array}{l}\text { Cast/ } \\
\text { Ethnicity }\end{array}$} & \multicolumn{3}{|c|}{ Religions of the Household Population } & \multicolumn{2}{c|}{ Total } \\
\cline { 2 - 7 } & Hindu & Buddhists & Kirat & Christian & Number & Percent \\
\hline Tharu & 513 & - & - & 139 & 652 & 64.7 \\
\hline Janajati & 37 & 78 & 45 & 18 & 178 & 17.7 \\
\hline Dalit & 56 & - & - & 41 & 97 & 9.6 \\
\hline $\begin{array}{l}\text { Brahmin/ } \\
\text { Chhetri }\end{array}$ & 78 & - & - & 2 & 80 & 8.0 \\
\hline Total & 684 & 78 & 45 & 200 & 1007 & 100 \\
\hline & 68.0 & 7.7 & 4.5 & 19.8 & 100 & \\
\hline
\end{tabular}

Source: Field Survey, 2015

Table 3 exhibits that Tharu population has been occupied the largest percentage in the 
study population with 64.7 percent which is followed by Janajati with 17.7 percent, Dalit with 9.6 percent and Brahmin/Chhetri with 8.0 percent respectively.

\section{Distribution of Respondents by Age and Sex}

Age and sex is the important factors in foreign labor migration. It plays a vital role in demographic and socio economic structure in the study area. The age of foreign labor migrants has been categorized in five years of age interval.

Table-4: Distribution of respondents by five years age and sex, 2015

\begin{tabular}{|l|c|c|c|c|c|c|}
\hline \multirow{2}{*}{ Age Group } & \multicolumn{4}{|c|}{ Migrants } & \multicolumn{3}{c|}{ Total } \\
\cline { 2 - 7 } & \multicolumn{2}{|c|}{ Male } & \multicolumn{2}{c|}{ Female } & \multicolumn{2}{c|}{ Percent } \\
\cline { 2 - 7 } & Number & Percent & Number & Percent & Number & 11.0 \\
\hline $15-19$ & 23 & 7.4 & 11 & 3.6 & 34 & 21.4 \\
\hline $20-24$ & 48 & 15.5 & 18 & 5.9 & 66 & 20.5 \\
\hline $25-29$ & 42 & 13.6 & 21 & 6.9 & 63 & 16.9 \\
\hline $30-34$ & 39 & 12.6 & 13 & 4.3 & 52 & 13.0 \\
\hline $35-39-$ & 28 & 9.0 & 12 & 4.0 & 40 & 10.4 \\
\hline $40-44$ & 22 & 7.1 & 10 & 3.3 & 32 & 6.8 \\
\hline $45-49$ & 12 & 3.9 & 9 & 3.0 & 21 & 100 \\
\hline Total & 214 & 69 & 94 & 31 & 308 & \\
\hline
\end{tabular}

Source: Field Survey, 2015

Table 4 shows that the highest percentage of foreign labor migrants $(21.4 \%)$ was found in age group of 20-24 years, followed by the age group of 25-29 years with 20.5 percent, age group 30-34 years with 16.9 percent, age group 35-39 years with 13.0 percent, age group 15-19 years with 11.0 percent, age group 40-44 years with 10.4 percent and only less percentage of foreign labor migrants is obtained in age group of 45-49 years with 6.8 percent respectively. The percentage of female is very low in comparison to male.

\section{Area of Land Holding by the Respondents}

In the last five decades, while the population has increased by nearly 3 fold, the volume of cultivated land has increased by less than 2 fold (CBS, 2014). Majority of the people in Nepal are directly or indirectly involved in agriculture due to the lack of employment opportunities. There is a great relationship between the land and foreign labor migration. Land holding refers the area of land covered by respondent's family for cultivation or Ghaderi. 
Table-5: Distribution of the respondents by area of land holding size, 2015

\begin{tabular}{|l|c|c|}
\hline Area of Land (Kattha) & Number & Percent \\
\hline$<5$ & 17 & 5.5 \\
\hline $5-10$ & 86 & 28.0 \\
\hline $10-15$ & 89 & 28.9 \\
\hline $15-20$ & 98 & 31.8 \\
\hline$>20$ & 15 & 4.9 \\
\hline Landless & 3 & 0.9 \\
\hline Total & 308 & 100 \\
\hline
\end{tabular}

Source: Field Survey, 2015

Table 5 exhibits that 31.8 percent of the respondents have $5-10$ Kattha land, followed by 28.9 percent 10-15 Kattha, 28.0 percent have 5-10 Kattha, 5.5 percent have less than 5 Kattha, 4.9 percent have more than 20 Kattha and less percentage of the households $(0.9$ $\%$ ) have not been holding the land.

\section{Destination Country by Foreign Labor Migrants (FLMs)}

Destination country means that country where labor migrants go for foreign labor. Desire of people to select the destination country for foreign employment is different from one to another. Their educational level plays a vital role to select the destination country. There are three categories of educational levels such as under SLC, SLC to Intermediate and Bachelor.

Table-6: Distribution of destination countries of foreign labor migration by the level of education, 2015

\begin{tabular}{|l|c|c|c|c|c|c|c|c|c|}
\hline \multirow{2}{*}{$\begin{array}{l}\text { Educational } \\
\text { Level }\end{array}$} & \multicolumn{6}{|c|}{ Destination Countries } & \multicolumn{3}{c|}{ Total } \\
\cline { 2 - 11 } & Malaysia & Qatar & UAE & $\begin{array}{c}\text { Saudi } \\
\text { Arabia }\end{array}$ & Kuwait & Israel & Oman & Number & Percent \\
\hline Under SLC & 86 & 14 & 3 & 57 & 2 & 1 & 1 & 164 & 53.2 \\
\hline $\begin{array}{l}\text { SLC to } \\
\text { Intermediate }\end{array}$ & 51 & 6 & 7 & 28 & 1 & - & 2 & 95 & 30.8 \\
\hline Bachelor & 19 & 15 & 3 & 4 & 5 & - & 3 & 49 & 16.0 \\
\hline Total & 156 & 35 & 13 & 89 & 8 & 1 & 6 & 308 & 100 \\
\hline Percent & 50.6 & 11.3 & 4.2 & 28.9 & 2.6 & 0.3 & 2.0 & 100 & \\
\hline
\end{tabular}

Source: Field Survey, 2015

Table 6 illustrations that migrants who have under SLC education level have highest 
percent $(53.2 \%)$, followed by migrants who have SLC to intermediate educational level by $(30.8 \%)$. The less percentage of the respondents who have bachelor degree is 16.0 percent. Likewise, Malaysia is selected by 50.6 percent of migrants as destination country which is followed by Saudi Arabia (28.9\%), Qatar (11.3\%), UAE (4.2\%), Kuwait (2.6\%), Oman $(2.0 \%)$ and Israel $(0.3 \%)$ respectively in the study area.

\section{Classification of Jobs in Destination Countries}

Type of job is categorized by agriculture, factory labor, hotel and restaurant, construction, driving, trading/business, security guard and housekeeping.

Table-7: Distribution of the foreign labor migration by the status of employments among destination countries, 2015

\begin{tabular}{|l|c|c|c|c|c|c|c|c|c|}
\hline \multirow{2}{*}{$\begin{array}{l}\text { Employment } \\
\text { Status }\end{array}$} & \multicolumn{7}{|c|}{ Destination Countries } & \multicolumn{3}{c|}{ Total } \\
\cline { 2 - 12 } & Malaysia & Qatar & UAE & $\begin{array}{c}\text { Saudi } \\
\text { Arabia }\end{array}$ & Kuwait & Israel & Oman & Number & Percent \\
\hline Agriculture & 8 & 2 & 1 & 4 & - & - & - & 15 & 4.9 \\
\hline Factory Labor & 168 & 8 & 4 & 18 & 5 & - & 4 & 207 & 67.2 \\
\hline Hotel/Restaurant & 14 & 6 & 1 & 8 & 4 & 1 & 2 & 36 & 11.7 \\
\hline Construction & 4 & 8 & 1 & 2 & 4 & - & - & 19 & 6.2 \\
\hline Driving & 6 & 7 & 1 & 9 & 1 & - & 1 & 25 & 8.1 \\
\hline Trading/Business & 2 & 2 & - & - & - & - & - & 4 & 1.3 \\
\hline Security guard & 1 & - & - & - & - & - & - & 1 & 0.3 \\
\hline Housekeeping & - & - & - & - & - & 1 & - & 1 & 0.3 \\
\hline Total & 203 & 33 & 8 & 41 & 14 & 2 & 7 & 308 & 100 \\
\hline Percent & 66.0 & 10.7 & 2.6 & 13.3 & 4.5 & 0.6 & 2.3 & 100 & \\
\hline
\end{tabular}

Source: Field Survey, 2015

Table 7 shows that 67.2 percent migrants are involved in as labor factory which is followed by hotels $(11.7 \%)$, driving $(8.1 \%)$, constructions $(6.2 \%)$, agriculture $(4.9 \%)$, business $(1.3 \%)$, security guards $(0.5 \%)$ and housekeeping $(0.3 \%)$ respectively in the study area. This table also exhibits that all type of foreign labor migrant's heap in Malaysia as 66.0 percent followed by Saudi Arabia (13.3\%), Qatar (10.7\%), Kuwait (4.5\%), UAE (2.6\%), Oman $(2.3 \%)$ and Israel $(0.6 \%)$ respectively. 


\section{Conclusion}

This study attempts to draw the conclusion that migrants from low privilege households and lack of skillful manpower, significant Tharu people are migrating to Gulf countries as foreign labor migration. It also exhibits that common Tharu people are involved in agriculture sector following the traditional occupation as they lack the employment opportunities and services in other sectors. Furthermore, this community is seen to cover low percentage of agriculture land in the study area. It is also found that majority of the foreign labor migrated to the Gulf countries from informal agents rather than formal institutions. It is also suggested that provisions for vocational training and skills should be provided to the migrant workers, so that they can have better opportunities in the international labor markets to earn more money and better jobs. Nepalese people are also facing language and communication problems in the destination countries. To conclude that, illiteracy, unskilled labor, lack of vocational training, language skill and different culture and religion are the great challenges for foreign labor migrants.

\section{References}

Central Bureau of Statistics (CBS). (2003). Population monograph of Nepal 2001. Kathmandu: National Planning Commission Secretariat, Central Bureau of Statistics, Nepal.

Central Bureau of Statistics (CBS). (2014). Population monograph of Nepal 2011, Vol. I. Kathmandu: National Planning Commission Secretariat, Central Bureau of Statistics and Nepal

Central Bureau of Statistics (CBS). (2014). Population monograph of Nepal 2011, Vol. II. Kathmandu: National Planning Commission Secretariat, Central Bureau of Statistics, Nepal

Central Bureau of Statistics (CBS). (2014). Population monograph of Nepal 2011, Vol. III. Kathmandu: National Planning Commission Secretariat, Central Bureau of Statistics, Nepal

Nyberg, S. (2002). Governing globalization: issues and institutions, cross border movements of people. London: Oxford University Press, United Kingdom.

United Nations (UN). (1973). Multilingual demographic dictionary. New York: Department of Economic and Social Affairs, United States. 